\title{
Value of alpha-fetoprotein and clinical characteristics in patients with liver neoplasm
}

\author{
J. B. XU' ${ }^{1}$, F. Z. QI ${ }^{1}$, G. XU' ${ }^{1}$, G. F. CHEN ${ }^{1}$, L. X. QIN², J. H. ZHANG ${ }^{1, *}$ \\ ${ }^{1}$ Department of General Surgery, Huaian First People's Hospital, Nanjing Medical University, Huai'an, Jiangsu; ${ }^{2}$ Department of Liver Surgery, \\ Zhongshan Hospital, Fudan University, Shanghai, China
}

*Correspondence: Jh_z02@hotmail.com

Received June 24, 2013 / Accepted August 20, 2013

\begin{abstract}
This article aimed to investigate the value of $\alpha$-fetoprotein (AFP) for the diagnosis of hepatocellular carcinoma (HCC) and to evaluate the relationship between AFP and various clinical variables of HCC comprehensively.

A retrospective study of postoperative patients diagnosed with liver neoplasm from two Chinese centers was enrolled in our study.

A total of 3050 patients were included. The best cut-off point of AFP for the diagnosis of HCC was $20 \mathrm{ng} / \mathrm{ml}$ with ideal sensitivity (69.74\%), specificity (91.18\%), LR (4.12) and YI (0.61). Non-HBV infection patients showed the highest specificity (94.44\%) but lowest sensitivity (60.13\%). In HBV infection Patients, HBsAg, HBeAb, and HBcAb positive patients had the highest sensitivity (79.55\%) and specificity (58.49\%). AFP levels increased significantly in symptomatic patients $(\mathrm{p}=0.011)$. Those patients with tumor sizes $\geq 10 \mathrm{~cm}$ had much higher serum AFP level compared with smaller tumors ones $(\mathrm{p}=0.014)$. AFP levels increased remarkably in patients with vascular invasion $(\mathrm{p}=0.015)$. Stepwise logistic regression showed tumor size $(\geq 10 \mathrm{~cm})$ was an independent predictor of elevated AFP (OR=2.743, 95\%CI: 1.167-6.447, P=0.021).

The best discriminating AFP value for the diagnosis of $\mathrm{HCC}$ is $20 \mathrm{ng} / \mathrm{ml}$; HBsAg, $\mathrm{HBeAb}$ and $\mathrm{HBcAb}$ positive patients have the optimal sensitivity and specificity; tumor size $\geq 10 \mathrm{~cm}$ is an independent predictor of elevated AFP.
\end{abstract}

Key words: hepatocellular carcinoma, alpha-fetoprotein, diagnosis, hepatitis virus B

Hepatocellular carcinoma (HCC) with an estimated 600,000 deaths per year is the seventh most common malignant cancer and the third leading cause of cancer-related deaths worldwide [1]. The most common risk factors of HCC are chronic hepatitis $B$ virus (HBV) or hepatitis $\mathrm{C}$ virus (HCV) infection. Nearly half of new cases of HCC are occurred in china, mainly due to more than one hundred million chronic hepatitis $\mathrm{B}(\mathrm{CHB})$ patients living in China $[2,3]$.

In 1980, Harada and his colleagues [4] suggested that those patients with elevated AFP values might be at greater risk for the development of HCC. However, high serum AFP levels have also been found in many other diseases including cirrhosis, biliary cancer, teratocarcinoma of the testis and metastatic hepatic carcinoma [5]. Since then, the value of AFP for the diagnosis of HCC has become a hot issue due to unstable sensitivity and specificity. Some previous studies reported that the sensitivity of $20 \mathrm{ng} / \mathrm{mL}$ was low in detection of early stage HCC $[6,7]$; and the Italian and the American Association for the Study of Liver Diseases guidelines considered a level $\geq 200 \mathrm{ng} / \mathrm{mL}$ as the cut-off point for diagnosis [6, 8]. However, these reports were limited by a small sample size and focused on patients with chronic liver disease (CLD). In recent years, more and more patients with early HCC have been detected due to follow-up of highrisk groups. Therefore, some researchers began to doubt the value of AFP in the diagnosis of early HCC and many new diagnostic biomarkers had been proposed to complement AFP, such as AFP mRNA, fucosylation index (FI) of AFP, DDK1, Des- $r$-carboxy prothrombin (DCP), Lens culinaris agglutinin reactive AFP (AFP-L3), Glypican-3 (GPC3), Chromogranin-A(CgA) and so on[9-14]. Nevertheless, they are not widely used due to financial and technological limits; AFP still is the golden standard of diagnostic serum markers for HCC.

The relationship between serum AFP level and clinicopathological features remains controversial. Although some 
Table 1. The serum level of AFP in the whole population

\begin{tabular}{|c|c|c|c|c|c|}
\hline \multirow[t]{2}{*}{ Group } & \multicolumn{4}{|c|}{$\operatorname{AFP}(n, \%)$} & \multirow[t]{2}{*}{ Total (\%) } \\
\hline & $<20 \mu \mathrm{g} / \mathrm{L}$ & $20-200 \mu \mathrm{g} / \mathrm{L}$ & $200-400 \mu \mathrm{g} / \mathrm{L}$ & $>400 \mu \mathrm{g} / \mathrm{L}$ & \\
\hline HCC & $748(24.52 \%)$ & $449(14.72 \%)$ & $497(16.30 \%)$ & $778(13.11 \%)$ & $2472(81.05 \%)$ \\
\hline Other liver lesions & $530(17.38 \%)$ & $35(1.15 \%)$ & $10(0.33 \%)$ & $3(0.10 \%)$ & $578(18.95 \%)$ \\
\hline Total & 1278 & 484 & 507 & 781 & 3050 \\
\hline
\end{tabular}

AFP, alpha-fetoprotein; HCC, hepatocellular carcinoma

clinical trials [15-17] had suggested that the elevation of serum AFP levels were positively correlated with tumor sizes, tumor number and vascular invasion, some studies [18] hold opposite opinions. Moreover, these studies were often limited by a small sample size and failed to analyze the relationship between AFP and clinical features comprehensively.

With above confusions in mind, we conducted this research. The first purpose of this article was to identify the best cut-off value of serum AFP level for the diagnosis of HCC; then to evaluate the diagnostic value of AFP $(\geq 20 \mathrm{ng} / \mathrm{mL})$ according to the virological status; the final purpose was to investigate the relationship between serum AFP level and clinical features comprehensively.

\section{Patients and methods}

Data collection. A retrospective analysis was conducted on all surgical patients who received a initial diagnosis of liver neoplasms in Zhongshan Hospital, Fudan University, Shanghai, China, from December, 1995, to June, 2005. We also analyzed all surgical patients from Huaian First People's Hospital, Nanjing Medical University, China, from January, 2005, to June, 2010. A total of 2000 patients from Zhongshan Hospital and 1050 patients from Huaian First People's Hospital were included in this study. Clinicopathologic data including sex, age, symptom, AFP value, HBV infection, $\mathrm{HCV}$ infection, liver function and pathological type and so on were extracted.

Critical of inclusion and exclusion. Inclusion criteria for patients were as follows: 1) All eligible patients were treated by surgery and had postoperative pathological results; 2) All patients suspicious of HCC had complete preoperative clinical data including symptom, tumor size, tumor number, serum AFP, HBV and HCV status and so on. Patients with the following situations were excluded: 1) Those patients were treated with other treatments including ethanol injection(PEI), percutaneous microwave coagulation therapy (PMCT), radiofrequency ablation (RFA) rather than surgery; 2) Those patients with missing data.

AFP classify and clinical variables. The vast majority of patients had ultrasound and AFP examination in a week before surgery. Serum samples were taken upon when limosis before initial treatment, and AFP level was measured by conventional assays (ECLIA). Detection of serum AFP values ranged from
0 to $400 \mathrm{ng} / \mathrm{ml}$, and all of the serum AFP values more than $400 \mathrm{ng} / \mathrm{ml}$ were recorded as $400 \mathrm{ng} / \mathrm{ml}$ in our study. The value of $20 \mathrm{ng} / \mathrm{mL}$ was upper limit of normal AFP. We divided serum AFP values into four groups: $<20 \mathrm{ng} / \mathrm{mL}, 20-200 \mathrm{ng} / \mathrm{mL}, 200 \mathrm{ng} / \mathrm{mL}$ and $400 \mathrm{ng} / \mathrm{mL}$. The value of $200 \mathrm{ng} / \mathrm{mL}$ and $400 \mathrm{ng} / \mathrm{mL}$ were considered as confirmatory tests for HCC diagnosis $[19,20]$. The cut-off for normal AFP levels $(<20 \mathrm{ng} / \mathrm{mL})$ was selected on the bases of the EASL guidelines [21] and previous studies on this topic [22].

Tumor size was based on the longest axis and estimated comprehensively with pathology, ultrasound, CT or MRI. When multiple tumors of HCC were present, the diameter of the largest one was measured and taken as the representative HCC diameter. Vascular invasion was defined as the macro and/or microvascular invasion.

Statistical analysis. Values were expressed as the mean \pm SD or median. Spearman's rank correlation was used to analyze the correlations between markers values. The univariate analysis on association between marker values and clinical variables was analyzed by the Wilcoxon rank-sum test and Kruskal-Wallis $\mathrm{H}$ test. A stepwise logistic regression was applied in multiple variables analysis.

The best cut-off was chosen as the value that maximized the Youden index (YI) (sensitivity + specificity - 1) or likelihood ratio (LR) ((probability of true positive + probability of true negative) / (probability of false positive + probability of false negative)) [23]. The positive likelihood ratio (PLR) and the negative likelihood ratio (NLR) were calculated by the following formula: PLR, probability of true positive/ probability of false positive; NLR, false negative probability/ true negative probability. Since positive (PPV) and negative (NPV) predictive values depend on the prevalence of the disease, these variables were also assessed considering a prevalence of HCC of $5 \%, 10 \%, 20 \%$ and $30 \%$, which was closer to a clinical setting[24-26].

$P$ value $<0.05$ was considered statistically significant. All statistical analysis was undertaken using the Stata software (version11: StataCorp, Texas, USA).

\section{Results}

Clinical features of patients. A total of 3050 patients (2472 HCC cases and 578 other liver neoplasms cases) were enrolled in this study. Of the 3050 patients, 2414 patients (79.15\%) were men and 636 patients $(20.84 \%)$ were women 
(male-to-female ratio 3.8:1). AFP levels in patients with HCC were significantly higher than in patients with other liver neoplasm $(\mathrm{p}<0.001)$. The mean serum level of AFP was $184.98 \pm 174.13 \mathrm{ng} / \mathrm{mL}$. The mean age was $51.52 \pm 12.86$ years old. $71.87 \%(2192 / 3050)$ patients were infected with HBV including $95.12 \%$ (2085/2192) in the HCC group and 4.05\% $(107 / 2192)$ in other liver neoplasm group. Only 52 patients (1.7\%) were infected with HCV.

AFP and clinical variables of patients with HCC. In HCC patients, sex did not affect the levels of serum AFP $(\mathrm{p}=0.76)$. However, AFP levels increased significantly in patients with symptom than in asymptomatic patients $(\mathrm{p}=0.011)$. AFP level in patients with tumor size $\geq 10 \mathrm{~cm}$ was the significantly higher than in patients with tumor size $5-10 \mathrm{~cm}$ and with tumor size $\leq 5 \mathrm{~cm}(\mathrm{P}=0.007)$. The AFP levels were significantly higher in patients with vascular invasion $(\mathrm{p}=0.015)$. No differences regarding tumor number

Table 2. AFP and clinical variables in HCC group

\begin{tabular}{|c|c|c|c|}
\hline Variables & N (\%) & $\operatorname{AFP}^{*}(\mu \mathrm{g} / \mathrm{L})$ & $\mathbf{P}$ \\
\hline \multicolumn{4}{|l|}{ Sex } \\
\hline Male & $2128(86.09 \%)$ & $189.36 \pm 175.23$ & \\
\hline Female & $344(13.91 \%)$ & $174.05 \pm 175.37$ & 0.76 \\
\hline \multicolumn{4}{|l|}{ HBV infection } \\
\hline Yes & $2085(84.35 \%)$ & $173.61 \pm 155.64$ & \\
\hline No & $387(15.66 \%)$ & $187.45 \pm 173.48$ & 0.566 \\
\hline \multicolumn{4}{|l|}{ HBV infection (Yes) } \\
\hline $\begin{array}{l}\mathrm{HBsAg}, \mathrm{HBeAg} \text { and } \mathrm{HBcAb} \\
\text { positive }\end{array}$ & $549(22.21 \%)$ & $199.50 \pm 189.84$ & \\
\hline $\begin{array}{l}\mathrm{HBsAg}, \mathrm{HBe} A b \text {, and } \mathrm{HBcAb} \\
\text { positive }\end{array}$ & $1053(42.60 \%)$ & $195.52 \pm 165.12$ & \\
\hline Others* & $870(35.19 \%)$ & $170.09 \pm 176.01$ & 0.673 \\
\hline \multicolumn{4}{|l|}{ Symptom } \\
\hline Yes & $695(28.11 \%)$ & $122.74 \pm 155.64$ & \\
\hline No & $1777(71.89 \%)$ & $209.77 \pm 176.43$ & 0.011 \\
\hline \multicolumn{4}{|l|}{ Tumor size } \\
\hline$\leq 5 \mathrm{~cm}$ & $1120(45.31 \%)$ & $149.21 \pm 166.86$ & \\
\hline $5-10 \mathrm{~cm}$ & $869(35.15 \%)$ & $218.21 \pm 176.04$ & \\
\hline$\geq 10 \mathrm{~cm}$ & $483(19.54 \%)$ & $238.23 \pm 180.44$ & 0.007 \\
\hline \multicolumn{4}{|l|}{ Tumor number } \\
\hline 1 & $2144(86.73 \%)$ & $176.23 \pm 173.60$ & \\
\hline 2 & 193(7.81\%) & $264.91 \pm 178.71$ & \\
\hline$\geq 3$ & $135(5.46 \%)$ & $253.18 \pm 179.55$ & 0.252 \\
\hline \multicolumn{4}{|l|}{ Vascular invasion } \\
\hline Yes & $174(7.04 \%)$ & $175.40 \pm 171.95$ & \\
\hline No & $2298(92.96 \%)$ & $316.03 \pm 166.63$ & 0.015 \\
\hline \multicolumn{4}{|l|}{ Child-pugh class } \\
\hline A & $1971(79.73 \%)$ & $180.39 \pm 172.24$ & \\
\hline $\mathrm{B}$ & $487(19.70 \%)$ & $243.09 \pm 202.57$ & \\
\hline $\mathrm{C}$ & $14(0.57 \%)$ & $264.75 \pm 103.49$ & 0.338 \\
\hline
\end{tabular}

AFP, alpha-fetoprotein; HCC, hepatocellular carcinoma; HBV, Hepatitis B Virus; ${ }^{*}$, those patients are infected with $\mathrm{HBV}$ and neither $\mathrm{HBsAg}, \mathrm{HBeAg}$, and $\mathrm{HBcAb}$ test positive nor $\mathrm{HBsAg}, \mathrm{HBeAb}$, and $\mathrm{HBcAb}$ test positive; ", mean $\pm \mathrm{SD}$ $(\mathrm{p}=0.252)$ and Child-Pugh class $(\mathrm{p}=0.338)$ were founded between groups (Table 2).

Logistic regression analysis of clinical variables and AFP levels. In the stepwise logistic regression models, all clinical variables were included including sex, age, symptom, glutamicpyruvic transaminase (ALT), glutamic oxalacetic transaminase (AST), serum total bilirubin (TBIL), HBV infection, tumour number, tumour size, vascular invasion and child-pugh class. In this model, only tumor size $(\geq 10 \mathrm{~cm})$ was independent predictor of elevated AFP concentrations $(\mathrm{OR}=2.743,95 \%$ CI: 1.167-6.447, $\mathrm{P}=0.021$ ).

AFP levels for the diagnosis of HCC. Table 1 depicts AFP levels in the whole population. Serum AFP level was significantly higher in HCC than control patients $(\mathrm{P}<0.001)$. Of the AFP level $<20 \mathrm{ng} / \mathrm{ml}, 24.52 \%$ cases with HCC and $17.28 \%$ cases with other liver neoplasma; the serum AFP levels in HCC group and the control group at 21-200, 200-400 and above $400 \mathrm{ng} / \mathrm{mL}$ were $14.72 \%$ vs $1.27 \%, 16.30 \%$ vs $0.39 \%$ and $13.11 \%$ vs $0.39 \%$, respectively.

Table 3 shows the pathology of all liver lesions in the population under study. In HCC group, 455 patients (18.41\%) had elevated alanine aminotransferase (ALT) and 2299 patients (93\%) with cirrhosis. Of the 578 cases with other liver neoplasma, 48 patients had elevated serum AFP level ( $>20 \mathrm{ng} / \mathrm{mL}$ ), including metastatic hepatic carcinoma $(\mathrm{n}=14)$, hepatic cavernous haemangioma $(n=11)$, cholangiocellular carcinoma or hepatoid adenocarcinoma $(\mathrm{n}=10)$, micronodular cirrhosis $(n=8)$, widespread necrosis $(n=3)$ and dysplastic nodule $(\mathrm{n}=2)$.

Table 4 describes the different levels of serum AFP for the diagnosis of HCC. The discriminating values for HCC diagnosis were divided into three groups: 20, 200 and $400 \mathrm{ng} / \mathrm{ml}$. When the cut-off value of $20 \mathrm{ng} / \mathrm{ml}$ was considered, we had the highest sensitivity (69.74\%), but with the lowest specificity (91.18\%). Moreover, this cut-off showed lower PLR (8.48) and NLR (0.33)

Table 3. Pathology of all liver lesions in the population under study

\begin{tabular}{lrcc}
\hline Pathology & Cases & $\begin{array}{c}\text { Percentage } \\
(\%)\end{array}$ & AFP $^{*}(\mu \mathrm{g} / \mathrm{L})$ \\
\hline HCC & 2472 & 81.05 & $185.30 \pm 174.71$ \\
Metastatic hepatic carcinoma & 201 & 6.59 & $19.40 \pm 51.35$ \\
Cholangiocellular carcinoma & 67 & 2.20 & $36.01 \pm 86.00$ \\
Micronodular cirrhosis & 20 & 0.66 & $44.90 \pm 75.79$ \\
Inflammatory granuloma & 9 & 0.30 & $7.52 \pm 5.67$ \\
Inflammatory pseudotumor & 2 & 0.07 & $4.70 \pm 0.75$ \\
Hepatic adenomas & 2 & 0.07 & $19.6 \pm 22.95$ \\
Hepatic cavernous haemangioma & 225 & 7.38 & $13.15 \pm 48.40$ \\
Dysplastic nodule & 33 & 1.08 & $17.91 \pm 54.28$ \\
Cryptococcosis & 2 & 0.07 & $9.57 \pm 5.18$ \\
Tuberculosis of the liver & 6 & 0.20 & $3.88 \pm 1.86$ \\
Lymphangioma & 1 & 0.03 & 5.67 \\
Others & 10 & 0.33 & $51.20 \pm 106.60$ \\
\hline
\end{tabular}

HCC, hepatocellular carcinoma; ${ }^{*}$, inconclusive results or widespread necrosis; ", mean \pm SD 
Table 4. Different serum levels of AFP for the diagnosis of HCC in the population under study

\begin{tabular}{lcccccc}
\hline Method & $\begin{array}{c}\text { Sensitivity } \\
\text { (\%) }\end{array}$ & $\begin{array}{c}\text { Specificity } \\
\text { (\%) }\end{array}$ & PLR & NLR & LR & YI \\
\hline AFP & & & & & & \\
20 & 69.74 & 91.18 & 8.48 & 0.33 & 4.12 & 0.61 \\
200 & 51.58 & 97.75 & 22.93 & 0.50 & 2.95 & 0.49 \\
400 & 31.47 & 99.13 & 36.17 & 0.69 & 1.88 & 0.30 \\
\hline
\end{tabular}

AFP, alpha-fetoprotein; HCC, hepatocellular carcinoma; PLR, positive likelihood ratio; NLR, negative likelihood ratio; LR, likelihood ratio; YI, youden index

but higher LR (4.12) and YI (0.61) than other two cut-offs. Therefore, the best cut-off for the analyses was $20 \mathrm{ng} / \mathrm{ml}$.

Table 5 reports the PPV and NPV of the AFP cut-offs in different HCC prevalence. PPV of $20 \mathrm{ng} / \mathrm{ml}$ was $77.21 \%$ but decreased to $29.39 \%$ at $5 \%$ tumor prevalence. NPV was $87.55 \%$ and rose to $98.28 \%$ at $5 \%$ prevalence. All cut-offs value attained to a good NPV (90\%) when a HCC prevalence of $10 \%$ was considered.

AFP and HBV infection. A total of 2192 (71.87\%) patients were infected with $\mathrm{HBV}$, and these patients had significantly higher AFP level compared with non-HBV infection ones $(P=0.001)$. However, in HCC group, HBV infection did not affect the probability of showing an elevated AFP ( $\mathrm{p}=0.566$ ); and there was no significant difference among patients with different virological status $(\mathrm{p}=0.673)$.

Table 6 shows the sensitivity and specificity of serum AFP level of $\geq 20 \mathrm{ng} / \mathrm{ml}$ according to the virological status. In HBV infection patients, $\mathrm{HBsAg}, \mathrm{HBeAg}$, and $\mathrm{HBcAb}$ test positive patients showed the highest sensitivity and specificity. Those patients with non-HBV infection showed the highest specificity in the whole population.

Table 5. PPV and NPV for the diagnosis of HCC in different HCC prevalence

\begin{tabular}{lccc}
\hline AFP & HCC prevalence (\%) & PPV (\%) & NPV (\%) \\
\hline 20 & 5 & 29.39 & 98.28 \\
& 10 & 46.77 & 96.44 \\
& 20 & 66.41 & 92.34 \\
& 30 & 77.21 & 87.55 \\
& 5 & 54.69 & 97.46 \\
& 10 & 71.81 & 94.78 \\
& 20 & 85.14 & 88.98 \\
400 & 30 & 90.76 & 82.49 \\
& 5 & 65.56 & 96.49 \\
& 10 & 80.08 & 92.49 \\
& 20 & 90.04 & 85.26 \\
& 30 & 93.94 & 77.14 \\
\hline
\end{tabular}

AFP, alpha-fetoprotein; HCC, hepatocellular carcinoma; PPV, positive predict value; NPV, negative predict value;
Table 6. The sensitivity and specificity of AFP of $>20 \mathrm{ng} / \mathrm{ml}$ according to the virological status

\begin{tabular}{lcc}
\hline Virological status & Sensitivity (\%) & Specificity (\%) \\
\hline HBV- & $60.13 \%$ & $94.44 \%$ \\
HBV+ & $71.42 \%$ & $57.01 \%$ \\
HBsAg, HBeAg, and HBcAb positive & $66.67 \%$ & $-\dagger$ \\
HBsAg, HBeAb, and HBcAb positive & $79.55 \%$ & $58.49 \%$ \\
HBV/others & $63.88 \%$ & $52.00 \%$ \\
\hline
\end{tabular}

AFP, alpha-fetoprotein; HBV, Hepatitis B Virus; ${ }^{*}$, those patients are infected with $\mathrm{HBV}$ and they are neither $\mathrm{HBs} \mathrm{Ag}, \mathrm{HBeAg}$, and $\mathrm{HBcAb}$ test positive nor $\mathrm{HBsAg}, \mathrm{HBeAb}$, and $\mathrm{HBcAb}$ test positive; $\dagger$, too few patients to calculate

\section{Discussion}

The diagnostic role of AFP in patients with $\mathrm{HCC}$ has been discussed for over 40 years and this debate is still open. This article is not an original one but, is the most comprehensive report with the largest sample size and the correlation between AFP levels and clinical variables.

The diagnosis of HCC is the fundamental way to improve long-term survival rates [27]. In our population, the best cutoff of AFP for the diagnosis of HCC is $20 \mathrm{ng} / \mathrm{ml}$. Firstly; this cut-off value $(20 \mathrm{ng} / \mathrm{ml})$ had a higher sensitivity but a little lower specificity comparing to the other two cut-offs (200ng/ $\mathrm{ml}$ and $400 \mathrm{ng} / \mathrm{ml})$. It meant that $449(18.16 \%)$ patients were diagnosed with HCC but $38(6.57 \%)$ patients misdiagnosed with HCC. However, when we rechecked these patients who were misdiagnosed with HCC, we found nearly half of patients were malignant tumor including metastatic hepatic carcinoma $(n=10)$ and cholangiocellular carcinoma $(n=6)$. Moreover, surgery was a suitable treatment for them. Secondly, we calculated the likelihood ratio which was not influenced by the prevalence of the disease to assess the authenticity of this cut-off. The cut-off of $20 \mathrm{ng} / \mathrm{ml}$ showed a rather good NLR but a low PLR which mainly due to the number of patients in HCC group was obviously larger than other liver neoplasm group. Lastly, this cut-off demonstrated significant advantages in LR and YI. From above we can draw a conclusion that the level of $20 \mathrm{ng} / \mathrm{ml}$ is the best cut-off for the diagnosis of HCC.

Besides the sensitivity and specificity of AFP value, we paid attention to PPV and NPV in this diagnostic test. In our results, with the HCC prevalence of 5\%, the NPV of AFP $(20 \mathrm{ng} / \mathrm{ml})$ became very high $(98.28 \%)$ indicating that most patients with a normal serum AFP were free from HCC. However, in the HCC prevalence of $5 \%$, this cut-off $(20 \mathrm{ng} / \mathrm{ml})$ showed a poor PPV (29.39\%) comparing to the cut-off of $200 \mathrm{ng} / \mathrm{ml}$ (54.69\%) and $400 \mathrm{ng} / \mathrm{ml}(65.56 \%)$. The main reason of this phenomenon was that HCC patients with the AFP level between 20 to $200 \mathrm{ng} / \mathrm{ml}$ accounted for a small proportion (14.72\%). However, it was unwise to ignore these HCC patients simply because they were in a small proportion. This conclusion was not consistent with some previous studies $[6,22,28]$, which obtained that the usage of AFP as a screening test for HCC in 
CLD patients should be abandoned. This difference may be mainly due to the different research objects enrolled in these studies (chronic liver disease patients in the previous studies VS liver lesion patients in our studies). In the report from Farinati [6], the main purpose was not to investigate the role of AFP in HCC screening or in identifying patients at risk. Moreover, the detail results of the sensitivity and specificity of AFP were not provided. In the other two reports $[22,28]$ AFP monitoring missed many HCC patients.

We also analyzed the clinical diagnosis value of AFP according to virological status. In $\mathrm{HBV}$ infection patients, we analyzed several common virological status including $\mathrm{HBsAg}, \mathrm{HBeAg}$ and $\mathrm{HBcAb}$ positive, $\mathrm{HBsAg}, \mathrm{HBe} A b$, and $\mathrm{HBcAb}$ positive and others. In patients with HCV infection, only 52 cases were enrolled, who was not included them in this study. We found that AFP value had the lowest sensitivity but the highest specificity in patients without viral infection at the cut-off of $20 \mathrm{ng} / \mathrm{ml}$. This conclusion seems result largely from the very low proportion of secretory cell in HCC patients without viral infection, which is in accord with seronegative non-Caucasian patients $[29,30]$ and Italian alcoholic patients [31]. Moreover, traditional view suggests that the appearance of $\mathrm{HBeAg}$ is a sign of viral replication and $\mathrm{HBeAb}$ positive prompts inhibition of viral replication. However, in our conclusion, the sensitivity and specificity of AFP reached the best value in patients with $\mathrm{HBsAg}, \mathrm{HBeAb}$ and $\mathrm{HBcAb}$ test positive who accounted for nearly half of total HBV-HCC patients. The reasons of this conclusion are as follows: (1) Currently, there are two major $\mathrm{HBV}$-specific mechanisms that contribute to the development of HCC [32]. The first is the integration of the viral genome into the host chromosome leading to the tumor-promoting genes activating, and/or tumor suppressor genes inactivating. The second mechanism is to alter host gene expression by affecting the intracellular signal transduction pathways. However, Fung and co-workers [33] reported that liver cirrhosis patients had a significantly higher medium serum HBV DNA level than those HCC patients and this conclusion was further confirmed by a report from China [34]. The main reason for this conclusion was that the integration of the HBV DNA into the host chromosome was more frequently in HCC patients than in liver cirrhosis patients. Similarly, HCC patients with $\mathrm{HBeAg}$ positive had a significantly higher medium serum HBV DNA level than $\mathrm{HBeAg}$ negative patients. So, we can speculate that the reduction of serum HBV DNA in HBeAg negative patients results from integration of the HBV DNA into the host chromosome. (2) The basal core promoter (BCP) of HBV controls the transcription of precore RNA which was responsible for the secretion of HBeAg. Jardi [35] reported that there was significantly difference in the prevalence of mutations of $\mathrm{BCP}$ between $\mathrm{HBeAg}$ positive and HBeAg negative patients. Therefore, the high proportion of $\mathrm{HBeAg}$ negative patients might partially due to the suppression of the secreted e antigen by the mutation of $\mathrm{BCP}$ in $\mathrm{HBeAg}$ positive patients [36].

In our study, no correlation was found between HBV infection and elevated serum AFP levels, which was consistent with some previous studies [37, 38]. However, some reports [39, 40] held that high AFP levels were more frequently observed in patients with HBV infection. One possible reason for this difference may be that the percentage of HBV infection in HCC patients was different among the studies. Our study showed that the elevated serum AFP level was associated with tumor size. This conclusion was consistent with some previous studies [17, 41], while some studies hold opposite opinions [18, 42]. This debate may mainly owe to the tumor size in other studies was smaller than in our study. In our study, patients were divided into three groups according to tumor size: $\leq 5 \mathrm{~cm}, 5-10 \mathrm{~cm}$ and $\geq 10 \mathrm{~cm}$, however in previous studies, patients were divided into five groups: $\leq 1,1.1-2,2.1-3,3.1-5$ and $>5 \mathrm{~cm}$. Vascular invasion is an established adverse prognostic factor in HCC patients [43], and previous studies $[16,44-46]$ had reported that tumor size and the serum AFP level were associated with vascular invasion. Our study also suggested a positive correlation between elevated AFP level and the presence of vascular invasion and tumor size increased significantly in patients with vascular invasion (Kruskal -Wallis test: $\mathrm{P}=0.01$, data not shown). AFP levels increased significantly in patients with symptom than in asymptomatic patients, which was not mentioned in previous studies. One possible reason was that symptomatic patients were relatively late compared with asymptomatic patients.

We are aware of the limitation of this study. Firstly, patients in this article have heterogenous due to a retrospective analysis; secondly, the number of patients in the control group was significantly fewer than it in the HCC group. However, we believe that these limitations do not greatly influence the conclusion of the study due to the large sample size and marked differences between the groups.

Acknowledgements: Thanks all the patients and clinical investigators who were involved in the studies.

\section{References}

[1] JEMAL A, BRAY F, CENTER MM, FERLAY J, WARD E, et al. Global cancer statistics. CA: a cancer journal for clinicians. 2011 Mar-Apr; 61: 69-90. http://dx.doi.org/ $10.3322 /$ caac. 20107

[2] SOERJOMATARAM I, LORTET-TIEULENT J, PARKIN DM, FERLAY J, MATHERS C, et al. Global burden of cancer in 2008: a systematic analysis of disability-adjusted life-years in 12 world regions. Lancet. 2012 Nov 24; 380: 1840-50. http:// dx.doi.org/10.1016/S0140-6736(12)60919-2

[3] KANAVOS P. The rising burden of cancer in the developing world. Annals of oncology : official journal of the European Society for Medical Oncology / ESMO. 2006 Jun; 17 Suppl 8: viii15-viii23.

[4] HARADA T, SHIGETA K, NODA K, FUKUMOTO Y, NISHIMURA H, et al. Clinical implications of alphafetoprotein in liver cirrhosis: five-year follow-up study. Hepato-gastroenterology. 1980 Jun; 27: 169-75.

[5] MIZEJEWSKI GJ. Levels of alpha-fetoprotein during pregnancy and early infancy in normal and disease states. Obstetrical 
\& gynecological survey. 2003 Dec; 58: 804-26. http://dx.doi. org/10.1097/01.OGX.0000099770.97668.18

[6] FARINATI F, MARINO D, DE GIORGIO M, BALDAN A, CANTARINI $M$, et al. Diagnostic and prognostic role of alpha-fetoprotein in hepatocellular carcinoma: both or neither? The American journal of gastroenterology. 2006 Mar; 101: 524-32. http://dx.doi.org/10.1111/j.1572$\underline{0241.2006 .00443 . \mathrm{x}}$

[7] SANAI FM, SOBKI S, BZEIZI KI, SHAIKH SA, ALSWAT K, et al. Assessment of alpha-fetoprotein in the diagnosis of hepatocellular carcinoma in Middle Eastern patients. Digestive diseases and sciences. 2010 Dec; 55: 3568-75. http://dx.doi. org/10.1007/s10620-010-1201-x

[8] TRAPE J, BOTARGUES JM, PORTA F, RICOS C, BADAL $\mathrm{JM}$, et al. Reference change value for alpha-fetoprotein and its application in early detection of hepatocellular carcinoma in patients with hepatic disease. Clinical chemistry. $2003 \mathrm{Jul}$; 49: 1209-11. http://dx.doi.org/10.1373/49.7.1209

[9] MALAGUARNERA G, GIORDANO M, PALADINA I, BERRETTA M, CAPPELLANI A, et al. Serum markers of hepatocellular carcinoma. Digestive diseases and sciences. 2010 Oct; 55: 2744-55. http://dx.doi.org/10.1007/s10620-0101184-7

[10] WANG Y, SHEN Z, ZHU Z, HAN R, HUAI M. Clinical values of AFP, GPC3 mRNA in peripheral blood for prediction of hepatocellular carcinoma recurrence following OLT: AFP, GPC3 mRNA for prediction of HCC. Hepatitis monthly. 2011 Mar; 11: 195-9.

[11] SHEN Q, FAN J, YANG XR, TAN Y, ZHAO W, et al. Serum DKK1 as a protein biomarker for the diagnosis of hepatocellular carcinoma: a large-scale, multicentre study. The lancet oncology. 2012 Aug; 13: 817-26. http://dx.doi.org/10.1016/ S1470-2045(12)70233-4

[12] GAO P, LI M, TIAN QB, LIU DW. Diagnostic performance of des-gamma-carboxy prothrombin (DCP) for hepatocellular carcinoma: a bivariate meta-analysis. Neoplasma. 2012; 59: 150-9. http://dx.doi.org/10.4149/neo 2012020

[13] CHOI JY, JUNG SW, KIM HY, KIM M, KIM Y, et al. Diagnostic value of AFP-L3 and PIVKA-II in hepatocellular carcinoma according to total-AFP. World journal of gastroenterology : WJG. 2013 Jan 21; 19: 339-46.

[14] AOYAGI Y, MITA Y, SUDA T, KAWAI K, KUROIWA T, et al. The fucosylation index of serum alpha-fetoprotein as useful prognostic factor in patients with hepatocellular carcinoma in special reference to chronological changes. Hepatology research : the official journal of the Japan Society of Hepatology. 2002 Aug; 23: 287.

[15] MITSUHASHI N, KOBAYASHI S, DOKI T, KIMURA F, SHIMIZU H, et al. Clinical significance of alpha-fetoprotein: involvement in proliferation, angiogenesis, and apoptosis of hepatocellular carcinoma. Journal of gastroenterology and hepatology. 2008 Jul; 23: e189-97. http://dx.doi.org/10.1111/ j.1440-1746.2008.05340.x

[16] SAKATA J, SHIRAI Y, WAKAI T, KANEKO K, NAGAHASHI $\mathrm{M}$, et al. Preoperative predictors of vascular invasion in hepatocellular carcinoma. European journal of surgical oncology : the journal of the European Society of Surgical Oncology and the British Association of Surgical Oncology. 2008 Aug; 34: 900-5.

[17] LIU C, XIAO GQ, YAN LN, LI B, JIANG L, et al. Value of alpha-fetoprotein in association with clinicopathological features of hepatocellular carcinoma. World journal of gastroenterology : WJG. 2013 Mar 21; 19: 1811-9.

[18] YAMAMOTO K, IMAMURA H, MATSUYAMA Y, HASEGAWA K, BECK Y, et al. Significance of alpha-fetoprotein and des-gamma-carboxy prothrombin in patients with hepatocellular carcinoma undergoing hepatectomy. Annals of surgical oncology. 2009 Oct; 16: 2795-804. http://dx.doi.org/10.1245/ s10434-009-0618-y

[19] PATERON D, GANNE N, TRINCHET JC, AUROUSSEAU MH, MAL F, et al. Prospective study of screening for hepatocellular carcinoma in Caucasian patients with cirrhosis. Journal of hepatology. 1994 Jan; 20: 65-71. http://dx.doi. org/10.1016/S0168-8278(05)80468-4

[20] Borzio M, Bruno S, Roncalli M, MELS GC, RAMELLA $\mathrm{G}$, et al. Liver cell dysplasia is a major risk factor for hepatocellular carcinoma in cirrhosis: a prospective study. Gastroenterology. 1995 Mar; 108: 812-7. http://dx.doi. org/10.1016/0016-5085(95)90455-7

[21] EASL-EORTC clinical practice guidelines: management of hepatocellular carcinoma. Eur J Cancer. 2012 Mar; 48: 599-641. http://dx.doi.org/10.1016/j.ejca.2011.12.021

[22] TREVISANI F, D'INTINO PE, MORSELLI-LABATE AM, MAZZELLA G, ACCOGLI E, et al. Serum alpha-fetoprotein for diagnosis of hepatocellular carcinoma in patients with chronic liver disease: influence of HBsAg and anti-HCV status. Journal of hepatology. $2001 \mathrm{Apr} ; 34: 570-5$. http://dx.doi. org/10.1016/S0168-8278(00)00053-2

[23] PEZZILLI R, MORSELLI-LABATE AM, MINIERO R, BARAKAT B, FIOCCHI M, et al. Simultaneous serum assays of lipase and interleukin- 6 for early diagnosis and prognosis of acute pancreatitis. Clinical chemistry. 1999 Oct; 45: 1762-7.

[24] BALLARDINI G, GROFF P, ZOLI M, BIANCHI G, GIOSTRA $\mathrm{F}$, et al. Increased risk of hepatocellular carcinoma development in patients with cirrhosis and with high hepatocellular proliferation. Journal of hepatology. 1994 Feb; 20: 218-22. http://dx.doi.org/10.1016/S0168-8278(05)80061-3

[25] COLOMBO M, DE FRANCHIS R, DEL NINNO E, SANGIOVANNI A, DE FAZIO C, et al. Hepatocellular carcinoma in Italian patients with cirrhosis. The New England journal of medicine. 1991 Sep 5; 325: 675-80. http://dx.doi.org/10.1056/ NEJM199109053251002

[26] ANDO E, KUROMATSU R, TANAKA M, TAKADA A, FUKUSHIMA N, et al. Surveillance program for early detection of hepatocellular carcinoma in Japan: results of specialized department of liver disease. Journal of clinical gastroenterology. 2006 Nov-Dec; 40: 942-8. http://dx.doi.org/10.1097/01. mcg.0000225675.14594.d6

[27] ROSSI L, ZORATTO F, PAPA A, IODICE F, MINOZZI M, et al. Current approach in the treatment of hepatocellular carcinoma. World journal of gastrointestinal oncology. 2010 Sep 15; 2 : 348-59.

[28] SHERMAN M, PELTEKIAN KM, LEE C. Screening for hepatocellular carcinoma in chronic carriers of hepatitis $B$ 
virus: incidence and prevalence of hepatocellular carcinoma in a North American urban population. Hepatology. 1995 Aug; 22: 432-8.

[29] KEW MC, HOUGHTON M, CHOO QL, KUO G. Hepatitis C virus antibodies in southern African blacks with hepatocellular carcinoma. Lancet. 1990 Apr 14; 335: 873-4. http://dx.doi. org/10.1016/0140-6736(90)90474-J

[30] TSAI JF, CHANG WY, JENG JE, HO MS, LIN ZY, et al. Frequency of raised alpha-fetoprotein level among Chinese patients with hepatocellular carcinoma related to hepatitis B and C. British journal of cancer. 1994 Jun; 69: 1157-9. http:// dx.doi.org/10.1038/bjc.1994.227

[31] KWON OS, JUNG YK, KIM YS, KIM SG, LEE JI, et al. Effect of alcohol on the development of hepatocellular carcinoma in patients with hepatitis B virus-related cirrhosis: a cross-sectional case-control study. The Korean journal of hepatology. 2010 Sep; 16: 308-14. http://dx.doi.org/10.3350/ kjhep.2010.16.3.308

[32] LEE AT, LEE CG. Oncogenesis and transforming viruses: the hepatitis B virus and hepatocellularcarcinoma--the etiopathogenic link. Frontiers in bioscience : a journal and virtual library. 2007; 12: 234-45.

[33] FUNG J, YUEN MF, YUEN JC, WONG DK, LAI CL. Low serum HBV DNA levels and development of hepatocellular carcinoma in patients with chronic hepatitis B: a case-control study. Alimentary pharmacology \& therapeutics. 2007 Aug 1; 26:377-82. http://dx.doi.org/10.1111/j.1365-2036.2007.03390. $\underline{\mathrm{x}}$

[34] WANG JH, ZHOU M, LI Y, DENG J, WU XX, et al. [Difference of HBV DNA levels and HBV genotypes between the patients with primary hepatocellular carcinoma and liver cirrhosis with hepatitis B]. Zhonghua shi yan he lin chuang bing du xue za zhi = Zhonghua shiyan he linchuang bingduxue zazhi $=$ Chinese journal of experimental and clinical virology. 2011 Aug; 25: 245-7.PMID:22097598

[35] JARDI R, RODRIGUEZ F, BUTI M, COSTA X, VALDES $A$, et al. Mutations in the basic core promoter region of hepatitis B virus. Relationship with precore variants and HBV genotypes in a Spanish population of HBV carriers. Journal of hepatology. 2004 Mar; 40: 507-14. http://dx.doi. org/10.1016/j.jhep.2003.11.015

[36] SUGIYAMA M, TANAKA Y, KURBANOV F, NAKAYAMA $\mathrm{N}, \mathrm{MOCHIDA} S$, et al. Influences on hepatitis B virus replication by a naturally occurring mutation in the core gene. Virology. 2007 Sep 1; 365: 285-91. http://dx.doi.org/10.1016/ j.virol.2007.04.004

[37] DOHMEN K, SHIGEMATSU H, IRIE K, ISHIBASHI H. Clinical characteristics among patients with hepatocellular carcinoma according to the serum levels of alpha-fetoprotein and des-y-carboxy prothrombin. Hepato-gastroenterology. 2003 Nov-Dec; 50: 2072-8.
[38] SHIMADA M, TAKENAKA K, FUJIWARA Y, GION T, KAJIYAMA K, et al. Des-gamma-carboxy prothrombin and alpha-fetoprotein positive status as a new prognostic indicator after hepatic resection for hepatocellular carcinoma. Cancer. 1996 Nov 15; 78: 2094-100. http://dx.doi.org/10.1002/(SICI)10970142(19961115)78:10<2094::AID-CNCR9>3.0.CO;2-O

[39] KANG SH, KIM DO Y, JEON SM, AHN SH, PARK JY, et al. Clinical characteristics and prognosis of hepatocellular carcinoma with different sets of serum AFP and PIVKA-II levels. European journal of gastroenterology \& hepatology. 2012 Jul; 24: 849-56. http://dx.doi.org/10.1097/ MEG.0b013e3283535c34

[40] HANN HW, FU X, MYERS RE, HANN RS, WAN S, et al. Predictive value of alpha-fetoprotein in the long-term risk of developing hepatocellular carcinoma in patients with hepatitis $\mathrm{B}$ virus infection--results from a clinic-based longitudinal cohort. Eur J Cancer. 2012 Oct; 48: 2319-27. http://dx.doi. org/10.1016/j.ejca.2012.02.065

[41] NAKAMURA S, NOUSO K, SAKAGUCHI K, ITO YM, OHASHI Y, et al. Sensitivity and specificity of des-gamma-carboxy prothrombin for diagnosis of patients with hepatocellular carcinomas varies according to tumor size. The American journal of gastroenterology. 2006 Sep; 101: 2038-43. http://dx.doi.org/10.1111/j.1572-0241.2006.00681.x

[42] LU XY, XI T, LAU WY, DONG H, XIAN ZH, et al. Pathobiological features of small hepatocellular carcinoma: correlation between tumor size and biological behavior. Journal of cancer research and clinical oncology. 2011 Apr; 137: 567-75. http:// dx.doi.org/10.1007/s00432-010-0909-5

[43] CHEN LT, CHEN MF, LI LA, LEE PH, JENG LB, et al. Longterm results of a randomized, observation-controlled, phase III trial of adjuvant interferon Alfa-2b in hepatocellular carcinoma after curative resection. Annals of surgery. 2012 Jan; 255: 8-17. http://dx.doi.org/10.1097/SLA.0b013e3182363ff9

[44] PAWLIK TM, DELMAN KA, VAUTHEY JN, NAGORNEY DM, NG IO, et al. Tumor size predicts vascular invasion and histologic grade: Implications for selection of surgical treatment for hepatocellular carcinoma. Liver transplantation : official publication of the American Association for the Study of Liver Diseases and the International Liver Transplantation Society. 2005 Sep; 11: 1086-92.

[45] IKAI I, ARII S, KOJIRO M, ICHIDA T, MAKUUCHI M, et al. Reevaluation of prognostic factors for survival after liver resection in patients with hepatocellular carcinoma in a Japanese nationwide survey. Cancer. 2004 Aug 15; 101: 796-802. http://dx.doi.org/10.1002/cncr.20426

[46] WAKAI T, SHIRAI Y, SAKATA J, KANEKO K, CRUZ PV, et al. Anatomic resection independently improves long-term survival in patients with T1-T2 hepatocellular carcinoma. Annals of surgical oncology. 2007 Apr; 14: 1356-65. http://dx.doi. org/10.1245/s10434-006-9318-Z 